\title{
CORPOS EM OBRAS: UM OLHAR SOBRE AS PRÁTICAS CORPORAIS EM BRASÍLIA
}

\section{Marta Simões Peres}

Curso: Doutorado em Sociologia

Data de defesa da tese: $1^{\circ}$ de abril de 2005

Orientador: Prof. Dr. João Gabriel Lima Cruz Teixeira

\section{Resumo}

A questão do culto ao corpo nas sociedades contemporâneas do Ocidente é enfocada a partir das práticas de atividade física. A revisão teórica percorre a trajetória do sujeito moderno desde seu advento até a atualidade, discutindo noções fundamentais da Sociologia para a compreensão do fenômeno da cultura somática.

A pesquisa de campo buscou conhecer a relação dos sujeitos com seus corpos e optou pela metodologia qualitativa, combinando questionário e entrevistas em profundidade. Pessoas de diferentes níveis socioeconômicos foram abordadas em quatro locais de prática de caminhada e ginástica de Brasília (DF): duas pistas ao ar livre e duas academias.

Os dados obtidos são relacionados às discussões teóricas, assim como são expostos os pontos em comum e as peculiaridades entre os diferentes locais de prática.

Palavras-chave: culto ao corpo, atividade física: academias e caminhada, narcisismo, lazer, consumo, classes sociais, Brasília. 